
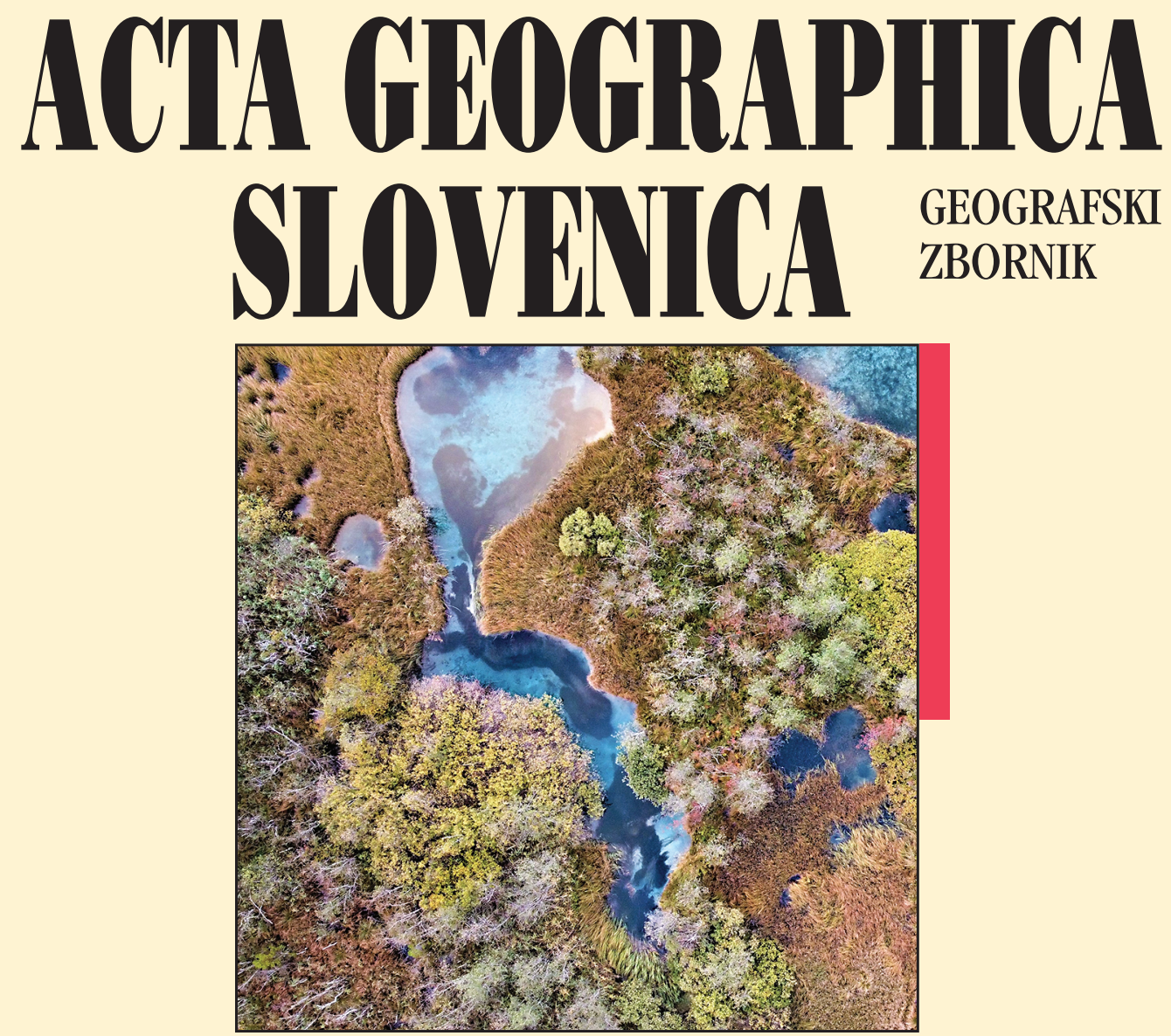


\section{ACTA GEOGRAPHICA SLOVENICA GEOGRAFSKI ZBORNIK 61-2 • 2021}

\section{Contents}

Đorđije VASILJEVIĆ, Milica BEGAN, Miroslav VUJIČIĆ, Thomas HOSE, Uglješa STANKOV

Does geosite interpretation lead to conservation? A case study of the Sićevo Gorge (Serbia)

Gabrijela POPOVIĆ, Dragiša STANUJKIĆ, Predrag MIMOVIĆ, Goran MILOVANOVIĆ, Darjan KARABAŠEVIĆ, Pavle BRZAKOVIĆ, Aleksandar BRZAKOVIĆ

An integrated SWOT - extended PIPRECIA model for identifying key determinants of tourism development: The case of Serbia

Robert KALBARCZYK, Eliza KALBARCZYK

Precipitation variability, trends and regions in Poland: Temporal and spatial distribution in the years 1951-2018

Ivana CRLJENKO, Matjaž GERŠIČ

A comparison of the beginnings of exonym standardization in Croatian and Slovenian

Tadej BREZINA, Jernej TIRAN, Matej OGRIN, Barbara LAA

COVID-19 impact on daily mobility in Slovenia

Maruša GOLUŽA, Maruška ŠUBIC-KOVAČ, Drago KOS, David BOLE

How the state legitimizes national development projects: The Third Development Axis case study, Slovenia

Tin LUKIĆ, Tanja MICIĆ PONJIGER, Biljana BASARIN, Dušan SAKULSKI, Milivoj GAVRILOV, Slobodan MARKOVIĆ, Matija ZORN, Blaž KOMAC, Miško MILANOVIĆ, Dragoslav PAVIĆ, Minučer MESAROŠ, Nemanja MARKOVIĆ, Uroš DURLEVIĆ, Cezar MORAR, Aleksandar PETROVIĆ Application of Angot precipitation index in the assessment of rainfall erosivity: Vojvodina Region case study (North Serbia)

Janij OBLAK, Mira KOBOLD, Mojca ŠRAJ

The influence of climate change on discharge fluctuations in Slovenian rivers

Vladimir STOJANOVIĆ, Dubravka MILIĆ, Sanja OBRADOVIĆ, Jovana VANOVAC, Dimitrije RADIŠIĆ

The role of ecotourism in community development: The case of the Zasavica Special Nature Reserve, Serbia

Marko V. MILOŠEVIĆ, Dragoljub ŠTRBAC, Jelena ĆALIĆ, Milan RADOVANOVIĆ Detection of earthflow dynamics using medium-resolution digital terrain models: Diachronic perspective of the Jovac earthflow, Southern Serbia

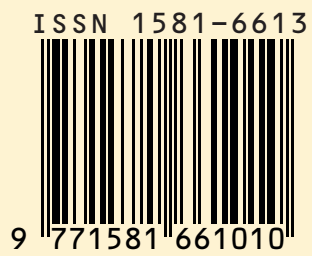




\section{HOW THE STATE LEGITIMIZES NATIONAL DEVELOPMENT PROJECTS: THE THIRD DEVELOPMENT AXIS CASE STUDY, SLOVENIA}

Maruša Goluža, Maruška Šubic-Kovač, Drago Kos, David Bole

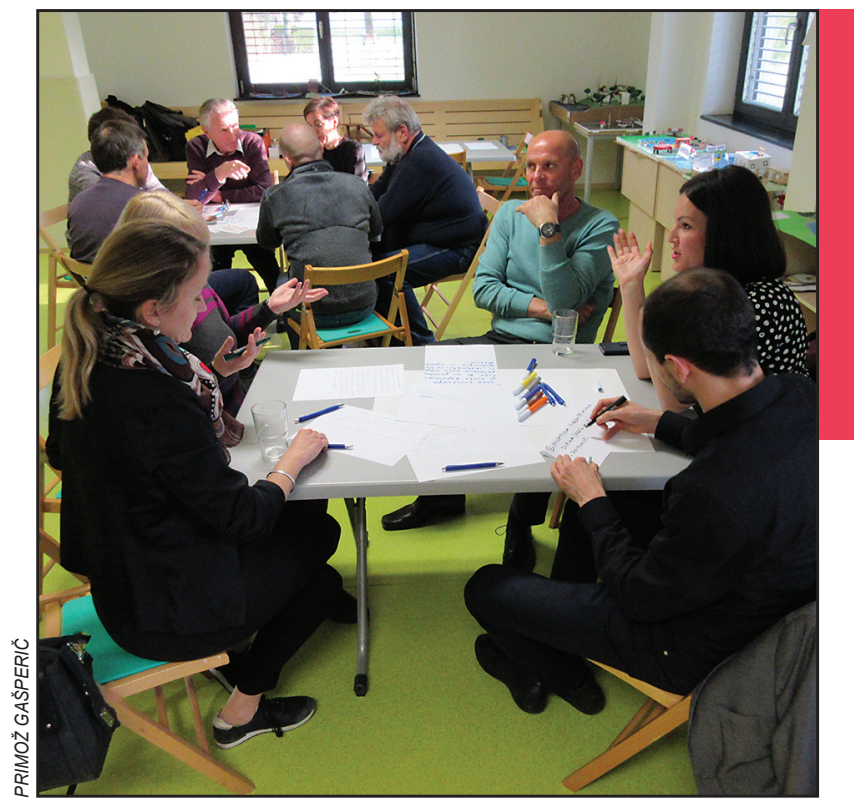

Public participation in a decision-making processes. 
DOI: https://doi.org/10.3986/AGS.9572

UDC: 711.122:711.7(497.4)

COBISS: 1.01

Maruša Goluža ${ }^{1}$, Maruška Šubic-Kovač², Drago Kos ${ }^{3}$, David Bole ${ }^{1}$

\title{
How the state legitimizes national development projects: The Third Development Axis case study, Slovenia
}

\begin{abstract}
We analyzed planning mechanisms and evaluated their performance in achieving legitimacy in infrastructure planning in Slovenia. Planning mechanisms were divided according to the concept of input, throughput and output legitimacy. We conducted a document analysis and interviews to assess their effectiveness in achieving legitimate decisions. Although the analyzed decision-making process declaratively promoted democratic principles, the mechanisms failed to satisfactorily enhance the legitimacy of decisions. The study revealed inadequate communication approaches, both in the decision-makers' relationship with the public and within the expert discourse. Accordingly, the study argues for more genuine communication with the public and within academia to address legitimacy challenges in increasingly conflictual decision-making processes.
\end{abstract}

KEY WORDS: deliberative governance, post-political spatial planning, qualitative research, citizen participation, transportation planning

\section{Kako država legitimira nacionalne razvojne projekte: primer tretje razvojne osi, Slovenija}

POVZETEK: V prispevku smo analizirali postopek načrtovanja infrastrukturnega projekta v Sloveniji in ocenili uspešnost uporabljenih pristopov za doseganje legitimnosti odločitev. Pristopi k načrtovanju so bili razdeljeni v tri sklope, glede na uveljavljen koncept vhodne, postopkovne in izhodne legitimnosti. Legitimnost uporabljenih prostorsko-načrtovalskih pristopov smo ugotavljali s pomočjo kvalitativnih metod, natančneje $\mathrm{z}$ analizo dokumentov in intervjuji. Raziskava je pokazala, da je največji legitimacijski primanjkljaj na področju komunikacije, ne le med odločevalci in javnostjo temveč tudi med posameznimi strokami. Iz tega sledi, da bi morali za večjo družbeno sprejemljivost v bodočih, čedalje bolj konfliktnih postopkih odločanja, prostorski načrtovalci nameniti več pozornosti kakovosti komunikacije in sporazumevanju med akterji.

KLJUČNE BESEDE: deliberativno upravljanje, post-politično prostorsko načrtovanje, kvalitativne metode, participacija civilne družbe, prometno načrtovanje

The article was submitted for publication on February $9^{\text {th }}, 2021$.

Uredništvo je prejelo prispevek 9. februarja 2021.

\footnotetext{
${ }^{1}$ Research Centre of the Slovenian Academy of Sciences and Arts, Anton Melik Geographical Institute marusa.goluza@zrc-sazu.si (https://orcid.org/0000-0002-2011-1547), david.bole@zrc-sazu.si (https://orcid.org/0000-0003-2773-0583)

${ }^{2}$ University of Ljubljana, Faculty of Civil and Geodetic Engineering, Ljubljana, Slovenia maruska.subic-kovac@fgg.uni-lj.si

${ }^{3}$ University of Ljubljana, Faculty of Social Sciences, Ljubljana, Slovenia drago.koss@gmail.com
} 


\section{Introduction: The necessary legitimacy of national spatial planning system}

Modern societies increasingly face a crisis of legitimacy in spatial planning and other public policies due to conflicts, the emergence of citizens' initiatives and an overall decline in social acceptance of public policies (Sager 1999; Kos 2002; Inch 2015). Decision-making is often value-based and requires trade-offs and long-term solutions (Rittel and Webber 1973; Innes and Booher 2010). Differentiated sectoral policies, science, and the division of labour between different levels tires of government often overlap spatially and substantively. Policy decisions are therefore increasingly difficult to make and justify (Healey 1997; Kos 2002). As a result of the legitimacy crisis, the core question of modern nation-states today is how the state is supposed to justify and maintain its position of control and responsibility for the implementation of public policies in front of the public - the people who are directly affected by these policies. Habermas addressed this issue as early as the 1970s, claiming that the state must intervene to limit adverse effects of the liberal market economy while allowing the economy to function (Plant 1982). The need for trustworthy planning is particularly relevant in the formulation of long-term development plans where outcomes cannot be expected immediately. In this context, Tyler (2001) argues that legitimate government institutions and their public policies are more efficient and less likely to generate public opposition. Public policies that are perceived as illegitimate are generally more conflictual, less feasible and also more expensive for the state. Legitimacy has therefore always been one of the central concerns of planning theorists and practitioners.

The concept of legitimacy in spatial planning theory is closely related to the balance between individual and public interests. It reflects the extent to which national policies and spatial plans (that are supposed to be in the public interest) are consistent with individual interests and opinions (Alexander 2002). Legitimacy is thus a powerful means of achieving efficiency in the implementation of national policies and development plans (Tyler 2001). It refers to substantive and procedural dimensions of decision-making processes. Substantively, it depends on the legitimacy and conformity to established norms, rules and processes relevant to the matter at hand. In procedural terms, legitimacy depends on whether and how the decision-making process enables relevant actors to participate. Legitimacy thus signifies shared beliefs about how a country should be governed as a political community. It concerns the rights of citizens as well as the rights and duties of the state (or those who govern). Legitimacy in this sense is closely related to the notion of justification. Decisions of the state are legitimate insofar as they are properly justified. In other words, policies and decisions of the state are legitimate if the decision-makers can demonstrate that the powers they have and use are just, right and reasonable (Bekkers, Dijkstra and Fenger 2007).

Despite various critiques that participatory processes cannot live up to their theoretical ideals in practice (e.g., Flyvbjerg 1998; Forester 1999; 2009; Flyvbjerg, Bruzelius, and Rothengatter 2003; Flyvbjerg and Richardson 2003; Hillier 2003; Innes and Booher 2010; Sager 2013), there remains a general consensus among theorists and practitioners that participatory planning approaches are crucial for legitimizing development projects (e.g... Forester 1993; Healey 1996; 1997; 2003; Innes 1996; Marega and Kos 2002). However, empirical studies have shown that in practice it is often carried out superficially (Nared et al. 2015) and perceived as a hindrance in decision-making processes. Tokenistic participation is particularly characteristic of post-socialist countries (Hafner Fink 2012; Pop-Eleches and Tucker 2013; Poljak Istenič and Kozina 2020). Stable power relations and the strategic functioning of actors in decision-making processes also prevent genuine collaboration and consensus-building (Flyvbjerg 1998; Flyvbjerg and Richardson 2003).

Nevertheless, little is known about the actual performance of spatial planning and its mechanisms for legitimizing national development projects in Slovenia (e.g. Nared et al. 2015; Goluža 2020). Several conflictual and protracted decision-making processes, especially in the field of transport and energy infrastructures in the past decades, have shown that legitimation processes in Slovenia have obviously failed. In addition, Slovenian spatial planning legislation has been amended several times after independence, with clear attempts to optimize the preparation of national spatial plans, also by limiting public participation. We therefore hypothesize that the Slovenian attitude towards public participation in spatial planning is a legacy of the former Yugoslav socialist economic and political system of self-government. The system, which was democratic in theory and granted considerable decision-making powers to the working population, proved to be inefficient in practice. Decision-making processes were still heavily influenced by politics and market relations and were also very time-consuming and unproductive (Centrih 2014). Thus, the self-governance 
system did not contribute to more democratic decision-making processes. On the contrary, the experience with the self-government system probably left traces of distrust in participatory decision-making that persisted even after Slovenia declared independence in 1991 and transitioned to liberal democracy. Although Slovenia has adopted the Aarhus Convention (Zakon o ratifikaciji ... 2004) and, as an EU member state, declares the idea of participation as necessary for the legitimacy of public decision-making, its planning laws require only a minimum of public participation. The purpose of this study is to examine how the Slovenian spatial planning system relates to legitimacy and how the adoption of democratic norms affects legitimacy processes in practice. There are two main objectives of this study. The first is to outline the planning mechanisms used in the decision-making process to legitimize the national development project (the northern part of the Third Development Axis, hereafter Third Development Axis) and the national spatial plan as the basis for its implementation. Secondly, the legitimacy of the applied mechanisms will be assessed through a qualitative analysis. The research will contribute to a better understanding of the planning mechanisms and their contribution to the legitimacy of national development projects. With a specific focus on the Slovenian case study, the research will in particular deepen the understanding of key legitimacy problems in spatial planning that Slovenia as a young democracy is facing today.

\section{Conceptual framework for assessing legitimacy of decision-making process: Input, throughput and output legitimacy}

Spatial planning is increasingly facing a crisis of legitimacy due to conflicting scientific viewpoints, uncertainties, time and financial constraints, and many other value-based, institutional, and worldview differences among actors that are difficult to bridge (Forester 1984; Wheeler 2020). Legitimacy, then, is an elusive and context-dependent concept that cannot easily be guaranteed by a universal approach to planning. Since there is no absolutely correct planning approach that would ensure intrinsically legitimate decisions, researchers have no choice but to analyse and learn from individual case studies. In order to evaluate planning approaches in terms of legitimacy, some authors propose to decompose the concept of legitimacy into three pillars: Input, Throughput and Output Legitimacy (e.g. Bekkers, Dijkstra and Fenger 2007; Schmidt 2012; Lieberherr and Thomann 2020), which are summarised in Table 1. The concept of input, throughput and output legitimacy is also used in this paper as it provides a systematic analytical means to evaluate decision-making processes.

Table 1: Norms for assessing democratic legitimacy in decision-making processes (adapted from Bekkers, Dijkstra and Fenger 2007).

\begin{tabular}{|c|c|c|}
\hline Input legitimacy & Throughput legitimacy & Output legitimacy \\
\hline $\begin{array}{l}\text { - Equal opportunities for participation in } \\
\text { decision-making process and influencing } \\
\text { the decisions; } \\
\text { - Representation of relevant interests; } \\
\text { - Openness of the governance practices } \\
\text { to respond to specific needs in society. }\end{array}$ & $\begin{array}{l}\text { - Realization of collective decision-making } \\
\text { (e.g., voting, deliberation, etc.); } \\
\text { - Who participate in decision-making } \\
\text { (e.g., public, experts, representatives } \\
\text { of public sector); } \\
\text { - Transparency; } \\
\text { - Balanced power relations. }\end{array}$ & $\begin{array}{l}\text { - How decisions taken tackle collective problems; } \\
\text { - Effectiveness and efficiency of decision-making } \\
\text { process; } \\
\text { - Accountability of decisions. }\end{array}$ \\
\hline
\end{tabular}

Input legitimacy refers to a quality of policymaking (Lieberherr and Thomann 2020). It concerns political equality, active citizenship and popular sovereignty in shaping spatial policies or plans. It depends on the opportunities given to citizens to participate, express their interests, engage and influence the decisionmaking process. When citizen participation is only indirect, input legitimacy depends on the quality of representation of interests and preferences by political intermediaries. Input legitimacy also refers to the openness of the agenda-setting process to citizens' demands and concerns. In this sense, it means the openness of governance practices to respond to (locally) specific needs in society (Bekkers, Dijkstra and Fenger 2007).

Throughput legitimacy refers to the quality of a governance process (Lieberherr and Thomann 2020), to rules and processes that define decision-making processes (Bekkers, Dijkstra and Fenger 2007). Since societal problems and conflicts require collective action, throughput legitimacy is related to the implementation of collective decision-making. Throughput legitimacy is related to the quality of participation of all rele- 
vant actors. According to Habermas, communication between all relevant actors should lead to a shared learning process that promotes mutual understanding and confronts and transforms the power of the state and capital (Healey 1996). It should be transparent and informative and balance the power relations between actors. With these prerequisites, throughput legitimacy comes closest to participatory democracy and the goals of the Aarhus Convention (Bekkers, Dijkstra and Fenger 2007).

The third aspect of legitimacy in the decision-making process is output legitimacy, which represents the government's ability to produce outcomes from decision-making processes that solve collective problems (Bekkers, Dijkstra and Fenger 2007). Output legitimacy focuses on whether the outcomes of the decision-making process are legitimate in terms of acceptability, rather than the process itself (Lieberherr and Thomann 2020). Output legitimacy refers to the efficiency and effectiveness of the outputs and outcomes of the implemented policy or plan. It is concerned with how the decisions made meet the originally stated goals of the policy or plan and how they respond to the expressed desires of the population. Output legitimacy also refers to the accountability of decision makers, both for the decisions and for the outcomes of those decisions. Therefore, decisions and their impacts should be based on a fully transparent provision of information (Bekkers, Dijkstra and Fenger 2007).

\section{Methodology}

\subsection{Case study selection}

The study is based on a case study approach. For our analysis, we chose the planning process for a motorway along the Third Development Axis that will extend from the Slovenian-Austrian border in the north to the Slovenian-Croatian border in the south. We focused specifically on Section F, which refers to the area between the existing A1 motorway and the town of Velenje (see Figure 1). The selection of the case study was based on information-oriented sampling (Flyvbjerg 2006), which was motivated by several reasons: 1) the Third Development Axis is one of the few major Slovenian infrastructure projects of the last decades and also one of the most notorious ones due to multiple problems of legitimacy and conflicts; 2) the process of preparing the national development plan for Section F was one of the most conflictual and lengthy decision-making processes in Slovenia; and 3) the case involved actors from different social spheres, e. g., from civil society, the public sector and experts.

\subsection{Methods}

Since legitimacy is a rather ambiguous theoretical concept that cannot be fully measured or quantified objectively, we have adopted a qualitative approach for our study, i.e. a document analysis. Documents related to the preparation of the national spatial plan, such as expert evaluations of alternatives, revisions, reports and minutes, are publicly available upon request from the Ministry of the Environment and Spatial Planning, which is also responsible for the implementation of the decision-making process. These documents were used to identify the applied planning mechanisms used by the State to legitimise the development project under study, the Third Development Axis. We have presented the applied mechanisms according to the concept of input, throughput and output legitimacy discussed in Chapter 2 in Table 2). Finally, we assessed the overall legitimacy of the observed decision-making process.

\section{Results: The analysis of decision-making process's legitimacy}

\subsection{Overview of the planning process and outline of the applied legitimizing planning mechanisms}

The motorway along the Third Development Axis is a national infrastructure project defined as one of the development priorities in the national Spatial development strategy of Slovenia (Odlok o strategiji ... 2004). 
Maruša Goluža, Maruška Šubic-Kovač, Drago Kos, David Bole, How the state legitimizes national development projects: ...

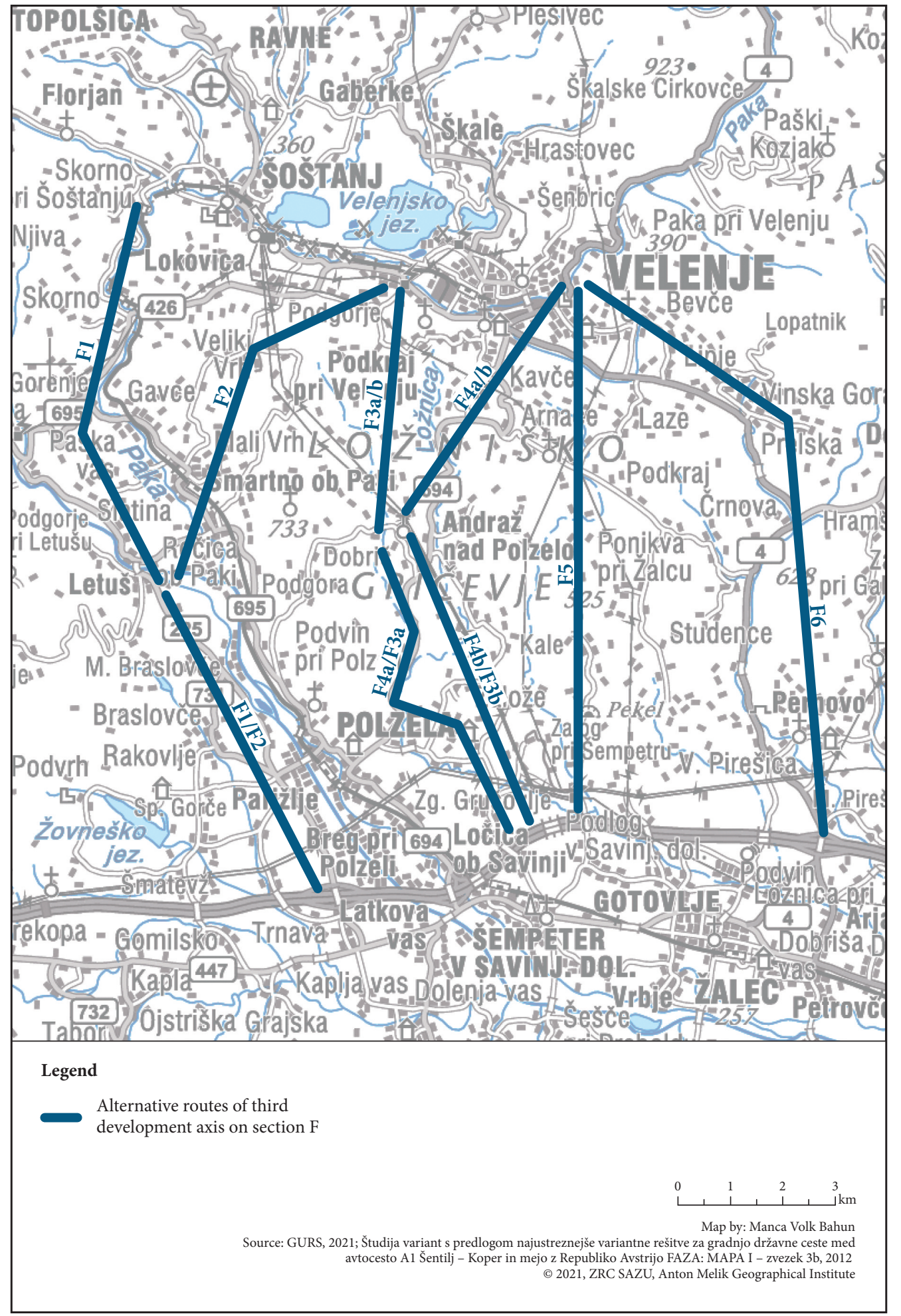


The main purpose of the motorway is to increase the economic competitiveness of the regions and cities (such as Slovenj Gradec, Dravograd, Velenje, Novo mesto) along the planned route, improve their accessibility and strengthen the institutional and economic links between them. In short, it is an instrument for strengthening economic, social and territorial cohesion (Projekt ... 2007). The motorway link, which would connect five Slovenian regions with the Austrian transport system in the north and the Croatian one in the south, should be implemented by 2013 (Resolucija ... 2004). As this is a major national infrastructure project, the state has a key role in legitimizing and implementing the planning process.

Following the launch of the project in 2004, the first spatial planning conference was organized by the Ministry of the Environment and Spatial Planning. This was a formally prescribed mechanism (Spatial Management Act 2002) aimed at soliciting and harmonizing the recommendations, guidelines and legitimate interests of local communities, the business community, interest groups and the organized public with regard to the preparation of the national spatial plan. In accordance with the interests expressed during the spatial planning conference, the preliminary expert analysis of the Third Development Axis was conducted. The analysis took into account various development scenarios, forecasts of traffic flows and various spatial, environmental and economic indicators. Suitable motorway alignment alternatives were identified for further analysis and review (Predhodne ... 2008).

The proposed motorway alternatives were further analysed and reviewed based on four groups of indicators: spatial, functional, environmental, and economic. The expert analysis ended in 2007 with the proposal of the most suitable variant for the Third Development Axis. For Section F, two alternatives received the highest score. Finally, the so-called F2 was selected as the most suitable because it was a better fit with the highest scoring alternative on the above-lying section (see Figure 1). However, F2 had two major drawbacks. It was relatively steep and would result in a significant loss of high-quality agricultural land (Študija ... 2008).

In 2008, the proposals for the best evaluated sections were presented to the ministries and representatives of the municipalities that would be affected by the new motorway. They were able to comment on the proposed motorway route and suggest optimizations, some of which were later included in the public displays and public hearings. During the public displays and hearings, fierce opposition arose from the local communities in the municipalities that would be affected by Section F, especially in the small rural municipality of Braslovče. They argued that the motorway would unjustifiably damage and cause loss of high-value and other agricultural land in the area typically used for agriculture.

The decision-making process was also reviewed at this stage by experts, as is customary for national development projects. The review revealed several shortcomings, such as that the objective of the whole project and its importance for regional development were not clear enough. They also emphasized that the project neglected anticipated demographic trends and the increasing importance of public transportation, which would reduce automobile use and the need for new motorway. The reviewers also pointed out the ambiguity and inconsistency in the use of various indicators. They claimed that the indicators used in evaluating the alternatives did not include an examination of the social acceptability of each alternative. The lack of clear explanations as to why one alternative is better than others was particularly evident in Section F, where two alternatives received the same score in the expert evaluation.

As the preparation of the national spatial plan as a whole proved to be very challenging due to several conflicts, the Ministry of Infrastructure arranged for the project to be divided into four separate spatial plans. One of these was the spatial plan for Section F. Sectoral ministries were asked to supplement their guidelines for the preparation of new spatial plans.

In 2010, a draft of the national spatial plan for Section $\mathrm{F}$ was presented to the ministries and mayors, as well as to the public in the municipalities. The partially optimized version of $\mathrm{F} 2$ again provoked opposition from the Ministry of Agriculture, Forestry and Food. It issued three negative opinions in relation with the environmental report. The Ministry of Agriculture, Forestry and Food opposed the construction of the motorway on legally protected, high value agricultural land and pointed out some procedural inconsistencies. They claimed that the chosen alternative was enforced without considering other alternatives.

The preparation of the national spatial plan for Section F continued with the inter-sectoral expert group that the national government had established in 2011 to evaluate the decision-making process. The expert group found similar inconsistencies as the reviewers. They highlighted the lack of justification of the project (in terms of expected traffic scenarios, financial resources, etc.), the vague explanations of the decisions on the alternatives, and the inadequate methodology for assessing impacts on agricultural land. The methodology allowed any type of construction on agricultural land as long as it was planned with mitigation measures. 
Thus, in the environmental report, any construction could be assessed as having an insignificant impact on agricultural land (Poročilo ... 2011). In 2012, due to conflicts, the national government initiated the study of other possible alternatives for the motorway on Section F, but all of them were discarded due to the crossing of Natura 2000 sites and other protected areas (Študija ... 2012).

The preparation of the national spatial plan for Section $\mathrm{F}$ was therefore continued for the optimized alternative F2. The proposal for the plan was put on public display in 2015. Three public hearings were held in three municipalities, Velenje, Šmartno ob Paki and Polzela. In Šmartno ob Paki, the public hearing was disrupted by local civic initiatives because they objected to the decision-making process and the selection of the final alternative itself. Despite the objections, the Ministry of the Environment and Spatial Planning continued the preparation of the National Spatial Plan, which was adopted by the national government in 2017. The municipalities of Braslovče, Polzela and Šmartno ob Paki therefore filed a constitutional review of the national spatial plan for the motorway (Decree ... 2017). They argued that the procedure for the preparation of the national spatial plan for Section F violated several legally protected rights and legally binding procedures. For example, they relied on the Slovenian Constitution, which grants citizens the right to participate in decision-making processes, the Aarhus Convention (Convention on ... 1998), which protects the right to access to information, public participation in decision-making and access to justice in environmental matters, as well as several other directives dealing with the impact of projects, plans and programs on the environment (Directive ... 2001; Directive ... 2011). In 2019, the Constitutional Court found that the Decree (2017) was not in conflict with the Slovenian Constitution (Odločba ... 2019).

\subsection{The evaluation of legitimacy of applied planning mechanisms}

In the previous subsection, we summarized the process of preparing the national spatial plan for the Third Development Axis, in Section F. Here we will assess the mechanisms that state actors used to legitimize the national development project. They have been presented chronologically and in line with the concept of input, throughput and output legitimacy in Table 2 below.

On paper, in the case of the Third Development Axis, the planning process began with mechanisms that promised high input legitimacy, such as the Spatial Planning Conference, which was a legally binding mechanism and aimed to harmonize the interests of actors, including civil society (Spatial Management Act 2002). A preliminary expert analysis was also carried out to define possible alternative variants and a coordination meeting was held with the mayors of the potentially affected municipalities. Local communities and experts were given the opportunity to influence decision-making by providing guidance, information and expertise (Pravilnik ... 2007). However, as the project became more concrete, conflicts between stakeholders increased, while the receptiveness of decision-makers to the plurality of interests and proposals from experts and civil society seemed to diminish. The subsequent process was essentially indifferent to the arguments of the opponents of alternative F2, which came from both experts and the local population in the area concerned. Decision-makers relied exclusively on seemingly rational expert assessments, even though several external experts (including reviewers, an inter-ministerial expert group, and agronomists) argued that these assessments were not entirely appropriate.

Throughput legitimacy refers to the communication aspect of the decision-making process and collective action in responding to problems and conflicts. The case study found that the decision-making process followed legally binding mechanisms, such as informing ministries and municipalities of decisions made and public displays of (propositional) spatial plans with public hearings. The Ministry of the Environment and Spatial Planning, which carried out the preparation of the national spatial plan, organized even more public displays and hearings, as required. This partly contributed to more transparency, and residents were also better informed about the project. However, it did little to improve the legitimacy of the decision-making process. The arguments of the opposing actors remained virtually the same throughout the decision-making process. The relocation of the motorway to an area of high-quality agricultural land was the biggest stumbling block, both for agronomists and for local farmers who depend on hop production and agriculture in general (Študija ... 2012). Conflicts between decision-makers and local residents opposed to the F2 variant reached their peak in 2015, when local citizens' groups violently disrupted the public hearing. Public displays and hearings could have facilitated consultation, but in practice they did not improve communication between actors. 
Table 2: The timeline of legitimizing planning mechanisms applied in the preparation of national spatial plan for Section F, according to input, throughput and output legitimacy.

\begin{tabular}{|c|c|c|c|}
\hline Year & Input legitimacy & Throughput legitimacy & Output legitimacy \\
\hline 2006 & $\begin{array}{l}\text { Spatial conference } \\
\text { Preliminary expert analysis of alternatives }\end{array}$ & & \\
\hline 2007 & $\begin{array}{l}\text { Coordination meeting with mayors of affected } \\
\text { municipalities } \\
\text { Expert evaluation of alternatives }\end{array}$ & & \\
\hline 2008 & $\begin{array}{l}\text { Ministries supplement their guidelines } \\
\text { for national spatial plan }\end{array}$ & $\begin{array}{l}\text { Display of the proposed route for ministries } \\
\text { and municipalities } \\
\text { Public display of the proposed variants } \\
\text { and public hearing }\end{array}$ & $\begin{array}{l}\text { Revision of the expert evaluation } \\
\text { Opposition in local communities } \\
\text { National spatial plan divided into four sections }\end{array}$ \\
\hline 2010 & & $\begin{array}{l}\text { Draft national spatial plan for F2 presented } \\
\text { to ministries and municipalities } \\
\text { Public display of draft national spatial plan } \\
\text { for F2 and public hearing }\end{array}$ & $\begin{array}{l}\text { Negative opinion of the Ministry of Agriculture, } \\
\text { Forestry and Food } \\
\text { Opposition of civic initiative in Braslovče }\end{array}$ \\
\hline 2011 & & & $\begin{array}{l}\text { Inter-sectoral expert group assessed } \\
\text { decision-making process }\end{array}$ \\
\hline 2012 & $\begin{array}{l}\text { Expert evaluation of other alternatives on } \\
\text { the Section F }\end{array}$ & & $\begin{array}{l}\text { National government requires expert analysis } \\
\text { of other alternatives on the Section F } \\
\text { Ministry of the Environment and Spatial } \\
\text { Planning proceeds with optimisation of } \\
\text { alternative F2 }\end{array}$ \\
\hline 2015 & & $\begin{array}{l}\text { Public display of draft spatial plan for } \\
\text { optimized F2 and public hearing }\end{array}$ & $\begin{array}{l}\text { Ministry of Agriculture, Forestry and Food } \\
\text { opposed to the proposed spatial plan }\end{array}$ \\
\hline 2016 & & $\begin{array}{l}\text { Public display of national spatial plan for } \\
\text { optimized F2 and public hearing }\end{array}$ & \\
\hline 2017 & & & $\begin{array}{l}\text { National government adopted spatial plan for } \\
\text { Section F } \\
\text { Spatial plan for Section F was submitted for } \\
\text { constitutional review }\end{array}$ \\
\hline 2019 & & & $\begin{array}{l}\text { The constitutional court rejected alleged } \\
\text { irregularities }\end{array}$ \\
\hline
\end{tabular}

Output legitimacy refers to the efficiency and accountability of decisions and is thus closely related to the reliability of the expert knowledge that supports the decisions. In the case of the Third Development Axis, the national government reviewed the legitimacy and efficiency of the decision-making process multiple times, for example through independent reviews and the establishment of an inter-sectoral expert group. These mechanisms uncovered multiple problems of legitimacy due to inconsistencies (e.g. in the justification of how the Third Development Axis would improve regional development, why it should be built as a four-lane motorway, or why on agricultural land), ambiguities (e.g. in the use and interpretation of indicators), and shortcomings (e.g. in not assessing the social acceptability of the project) in the decision-making process. There was also opposition from the Ministry of Agriculture, Forestry and Food because the proposed motorway conflicted with sectoral (agricultural) legislation that protects agricultural land.

In an effort to increase the legitimacy of the motorway and facilitate conflict resolution, decision-makers decided to split the Third Development Axis project into four separate spatial plans (Študija ... 2012). However, Section F remains controversial and illegitimate even after the government adopted the spatial development plan. The municipalities affected by the planned motorway submitted the Decree (2017) for 
constitutional review in 2017, but the Constitutional Court rejected the alleged irregularities in 2019 (Odločba ... 2019). As the conflicts remained unresolved and the adopted spatial plan did not achieve social acceptance, expert consent or the approval of the Ministry of Agriculture, Forestry and Food, the overall legitimacy in this regard proved weak.

\subsection{Discussion: The role of the state in providing legitimate decision-making}

The case study showed that the procedural measures used to legitimize the project were not sufficient to increase the legitimacy of the decision-making process as a whole. With the exception of the spatial conference and the preliminary expert analysis, which allowed for deliberation and co-decision-making in the initial phase of the project, the other mechanisms did not contribute to achieving a consensual and legitimate decision. The communication aspect of decision-making was limited to public displays and hearings, which did not allow for argumentation between the actors but for mutual persuasion. Public displays and hearings are commonly known as mechanisms that aim to inform citizens while allowing minimal citizen influence on decisions. According to Arnstein (1969), they fall into the category of tokenistic approach to public participation and give the false impression that decisions are made with public consent (Nared et al. 2015).

The case study revealed an inherently conflictual nature of spatial planning that resulted in a protracted and erratic decision-making process. The state, represented by ministries, the government and municipalities, did not act together and there was a lack of long-term political commitment to the project. The case study showed that there was no genuine communication not only between state actors, but also between experts and civil society. Weak input and throughput pillars of legitimacy also led to eroded legitimacy of the final decision. The constitutional review of the decision-making process, several expert opinions, and opposition from the Ministry of Agriculture, Forestry and Food made it clear that the adopted motorway route was considered illegitimate not only by local communities, but also by experts and politicians. The decision-making process revealed that some of the claims questioned by experts and civil society (especially those related to the environment and sustainable transport planning) were not intended for wider public and expert or scientific discourse. Moreover, government decision-makers did little to increase accountability for the outcomes of decision-making processes. Similar to the findings of Flyvbjerg (1998), the decision-making process analysed demonstrates how power relations and taken-for-granted discourses between certain groups of actors prevent the ideas and demands of others from coming to fruition or at least opening public debate and consideration.

The case study examined in this paper shows a vicious circle of stable power relations that have not fundamentally changed with the transition to liberal democracy, the ratification of the Aarhus Convention or the accession to the EU. Central decision-making power over the motorway project has remained in the hands of narrow circle of decision-makers and experts. On the contrary, there has been little room to reconcile the plurality of interests and opinions among stakeholders, whether from the public sector, wider circle of experts and academia, or civil society. Low level of trust in public institutions and tokenistic participatory approaches, typical of countries in the Central and Eastern Europe (Marinova 2011), are obviously also present in Slovenia. In Slovenia, public trust in the government is markedly low (Public ... 2018), which means that the state should make even more efforts to legitimize projects through participatory approaches. The participatory approach to planning was recognized as important in legitimizing national policies. The decision-making process even went beyond the number of formally required public displays and hearings. Nevertheless, these measures did not strengthen mutual trust between actors or bring them closer to a common, accountable and legitimate solution. In this respect, the transition in Slovenia has so far been only partially successful. Awareness of the importance of public participation for legitimate public policies has certainly increased, but there is an apparent lack of will on the part of actors to put this principle into practice and participate in a genuine decision-making process.

The concept of input, throughput, and output legitimacy provides a useful and systematic tool not only for analysis but also for raising awareness of the various aspects of acquiring legitimacy. As such, it is very informative for spatial planners and decision-makers who, in most cases, represent 'the state' in decisionmaking processes. It argues for more open, transparent and adaptive spatial planning processes to achieve greater legitimacy in future decision-making processes, not only in infrastructure planning but in spatial planning in general. The case study suggests that the mechanisms formally prescribed by the state to legitimize 
projects facilitate participation (input legitimacy) and shows that the Slovenian national spatial planning system is relatively open to plurality of interests. Nevertheless, communication between actors appeared rather symbolic and remained on the lower rungs of the participation ladder (Arnstein 1969). The adherence to formalistic decision-making processes rather than the promotion of an adaptive and deliberative approach may be the legacy of the earlier system of self-government. Indeed, state decision-makers' fear of losing control if too many decision-making powers are distributed among different actors, even the lay public, is understandable. This may lead to uncritical, unproductive and time-consuming decision-making processes (Centrih 2014), as was the case in the former Yugoslavia's self-government system. Scientific input (not limited to formally selected four domains of expert analyses) should therefore be crucial to justify why one option is better than the other. To increase the legitimacy of throughput, the state should make much more effort to balance power relations and adapt to possible (unexpected) conflicts. Certain concerns of actors, especially in cases where similar criticisms of the project are voiced by both citizens and experts, should be discussed more transparently (e.g., environmental concerns). Any decision or exclusion of a particular option should be publicly deliberated and justified with the broadest possible (expert and public) consensus. Adjusting the formally prescribed decision-making process in such cases should not be seen as an obstacle, but as a moral obligation of the state in changing the environment for present and future generations. Only when the decision-making process allows different voices to be heard, and when collective decisions are based on deliberation and soundly justified (rather than being the result of tokenistic persuasion), can decision-makers make more legitimate and accountable decisions (output legitimacy).

\section{Conclusion}

The case study analyzed has highlighted several legitimacy problems, which do not depend not only on compliance with formal, procedural mechanisms to facilitate participation, but above all require a change in actors' attitudes towards co-decision. Since legitimacy is a context-dependent and rather ambiguous concept that cannot be easily determined and achieved, the ideal decision-making process cannot be prescribed or formalized. However, being aware of the legitimacy deficits of past decision-making processes is the only way to gradually improve the legitimacy of future processes. The decision-making process analyzed in this paper showed rigidity and adherence to legally binding planning mechanisms that did not significantly enhance the legitimacy of the project. The principles of participatory planning, which encompass the concept of legitimacy, have remained untapped and represent potential that could enhance the legitimacy of national development projects and government agencies themselves. However, the implementation of the principles of participatory planning would inevitably require the allocation of decision-making powers.

ACKNOWLEDGEMENTS: The authors thank the Slovenian Research Agency for funding the core program Geography of Slovenia (P6-0101) and the junior researchers postgraduate research program. Both funds provided support for publishing these findings.

\section{References}

Alexander, E. R. 2002: The public interest in planning. From legitimation to substantive plan evaluation. Planning Theory 1-3. DOI: https://doi.org/10.1177/147309520200100303

Arnstein, S. 1969: A ladder of citizen participation. Journal of the American Planning Association 35-4. DOI: https://doi.org/10.1080/01944366908977225

Bekkers, V., Dijkstra, G., Fenger, M. 2007: Governance and the democratic deficit. Assessing the democratic legitimacy. London, New York. DOI: https://doi.org/10.4324/9781315585451

Centrih, L. 2014: The road to collapse. The demise of the League of Communists of Yugoslavia. Research Paper Series of Rosa Luxemburg Stiftung Southeast Europe 2. Internet: https://arhiv.rosalux.rs/en/ artikl.php?id=410 (4.7.2021) 
Decree on the national spatial plan for the construction of the national road from the A1 Šentilj-Koper motorway ramp at Šentrupert to the Velenje-south ramp. Uradni list Republike Slovenije 3/2017. Ljubljana.

Directive 2001/42/EC of the European Parliament and of the Council of 27 June 2001 on the assessment of the effects of certain plans and programmes on the environment. Official Journal 197, 21. 7. 2001.

Directive 2011/92/EU of the European parliament and of the Council of 13 December 2011 on the assessment of the effects of certain public and private projects on the environment. Official Journal 26, 28. 1. 2012.

Flyvbjerg, B. 1998: Rationality and power. Democracy in practice. Chicago.

Flyvbjerg, B. 2006: Five misunderstandings about case-study research. Qualitative Inquiry 12-2. DOI: https://doi.org/10.1177/1077800405284363

Flyvbjerg, B., Bruzelius, N., Rothengatter, W. 2003: Megaprojects and risk. An anatomy of ambition. Cambridge. DOI: https://doi.org/10.1017/CBO9781107050891

Flyvbjerg, B., Richardson, T. 2003: Planning and Foucault. In search of the dark side of planning theory. Planning Futures. New Directions for Planning Theory. London, New York.

Forester, J. 1984: Bounded rationality and the politics of muddling through. Public Administration Review 44-1.

Forester, J. 1993: Critical theory, public policy, and planning practice. Toward a critical pragmatism. Albany.

Forester, J. 1999: The deliberative practitioner. Encouraging participatory planning processes. Cambridge.

Forester, J. 2009: Dealing with differences. Dramas of mediating public disputes. Oxford, New York.

Goluža, M. 2020: Planning major transport infrastructure. Benefits and limitations of the participatory decision-making processes. Participatory research and planning in practice. The Urban Book Series. Cham. DOI: https://doi.org/10.1007/978-3-030-28014-7_12

Hafner Fink, M. 2012: Political participation, democratisation and citizens' values in Europe. Teorija in praksa 49-3.

Healey, P. 1996: The communicative turn in planning theory and its implications for spatial strategy formation. Environment and Planning B: Planning and Design 23-2. DOI: https://doi.org/10.1068/b230217

Healey, P. 1997: Collaborative planning. Shaping places in fragmented societies. London. DOI: https://oi.org/ 10.1007/978-1-349-25538-2

Healey, P. 2003: Collaborative planning in perspective. Planning Theory 2-2. DOI: https://doi.org/10.1177/ 14730952030022002

Hillier, J. 2003: ‘Agon'izing over consensus. Why Habermasian ideals cannot be 'real'. Planning Theory 2-1. DOI: https://doi.org/10.1177/1473095203002001005

Inch, A. 2015: Ordinary citizens and the political cultures of planning. In search of the subject of a new democratic ethos. Planning Theory 14-4. DOI: https://doi.org/10.1177/1473095214536172

Innes, I. E., Booher, D. E. 2010: Planning with complexity. An introduction to collaborative rationality for public policy. London, New York. DOI: https://doi.org/10.4324/9781315147949

Innes, J. E. 1996: Planning through consensus building. A new view of the comprehensive planning ideal. Journal of the American Planning Association 62-4. DOI: https://doi.org/10.1080/01944369608975712

Kos, D. 2002: Praktična sociologija za načrtovalce in urejevalce prostora. Ljubljana.

Lieberherr, E., Thomann, E. 2020: Linking throughput and output legitimacy in Swiss forest policy implementation. Policy Sciences 53. DOI: https://doi.org/10.1007/s11077-020-09374-3

Marega, M., Kos, D. 2002: Aarhuška konvencija v Sloveniji. Strokovna priporočila za implementacijo Konvencije o dostopu do informacij, udeležbi javnosti pri odločanju in dostopu do pravnega varstva v okoljskih zadevah. Ljubljana. Internet: http://web.bf.uni-lj.si/students/vnd/knjiznica/aarhuska/ strokovna_priporocila.pdf (10. 8. 2021).

Marinova, D. M. 2011: When government fails us. Trust in post-socialist civil organizations. Democratization 18-1. DOI: https://doi.org/10.1080/13510347.2011.532623

Nared, J., Razpotnik Visković, N., Cremer-Schulte, D., Brozzi, R., Cortines Garcia, F. 2015: Achieving sustainable spatial development in the Alps through participatory planning. Acta geographica Slovenica 55-2. DOI: https://doi.org/10.3986/AGS.1631

Odločba o ugotovitvi, da Uredba o državnem prostorskem načrtu za državno cesto od priključka Šentrupert na avtocesti A1 Šentilj-Koper do priključka Velenje jug ni v neskladju z Ustavo. Uradni list Republike Slovenije 36/2019. Ljubljana.

Odlok o strategiji prostorskega razvoja Slovenije. Uradni list Republike Slovenije 76/2004. Ljubljana. 
Plant, R. 1982: Jurgen Habermas and the idea of legitimation crisis. European Journal of Political Research 10.

Poljak Istenič, S., Kozina, J. 2020: Participatory planning in a post-socialist urban context. Experience from five cities in Central and Eastern Europe. Participatory Research and Planning in Practice. The Urban Book Series. Cham. DOI: https://doi.org/10.1007/978-3-030-28014-7_3

Pop-Eleches, G., Tucker, J. A. 2013: Associated with the past? Communist legacies and civic participation in post-communist countries. East European Politics and Societies 27-1. DOI: https://doi.org/10.1177/ 0888325412465087

Poročilo medresorske delovne skupine za evalvacijo dosedanjih postopkov pri prostorskem umeščanju državne ceste od priključka na avtocesti A1 pri Šentrupertu do priključka Velenje jug. Predlog za obravnavo, številka: 350-72/2010/197-0034188, 2011. Generalni sekretariat Vlade Republike Slovenije. Ljubljana.

Pravilnik o vsebini, obliki in načinu priprave državnih in občinskih lokacijskih načrtov ter vrstah njihovih strokovnih podlag. Uradni list Republike Slovenije 99/2007. Ljubljana.

Predhodne analize in določitev alternative za nadaljnje vrednotenje in primerjavo. DARS, 2008. Ljubljana. Projekt celovitega razvoja območja tretje razvojne osi. Zvezek 1. Zbirno poročilo. Služba Vlade Republike Slovenije za lokalno samoupravo in regionalno politiko in Ministrstvo za okolje in prostor, 2007. Ljubljana.

Resolucija o nacionalnem programu izgradnje avtocest $v$ Republiki Sloveniji. Uradni list Republike Slovenije 50/2004. Ljubljana.

Rittel, H. W. J., Webber, M. M. 1973: Dilemmas in a general theory of planning. Policy Science 4. DOI: 1 https://doi.org/10.1007/BF01405730

Sager, T. 1999: The rationality issue in land-use planning. Journal of Management History 5-2. DOI: https://doi.org/10.1108/13552529910249869

Sager, T. 2013: Collective action. Balancing public and particularistic interests. The Oxford Handbook of Urban Planning. Oxford. DOI: https://doi.org/10.1093/oxfordhb/9780195374995.013.0002

Schmidt, V. A. 2012: Democracy and legitimacy in the European Union revisited. Input, output and 'throughput'. Political Studies 61-1. DOI: https://doi.org/10.1111/j.1467-9248.2012.00962.x

Spatial Management Act. Uradni list Republike Slovenije 110/2002. Ljubljana.

Študija variant s predlogom najustreznejše variantne rešitve za gradnjo državne ceste med avtocesto A1 Šentilj-Koper in mejo z Republiko Avstrijo. DARS. Maribor, 2008.

Študija variant $s$ predlogom najustreznejše variantne rešitve za gradnjo državne ceste med avtocesto A1 Šentilj-Koper in mejo z Republiko Avstrijo. DARS. Maribor, 2012.

Tyler, T. R. 2001: A psychological perspective on the legitimacy of institutions and authorities. The psychology of legitimacy. Emerging perspectives on ideology, justice, and intergroup relations. Cambridge.

Wheeler, G. 2020: Bounded rationality. The Stanford Encyclopedia of Philosophy. Internet: https://plato.stanford.edu/archives/fall2020/entries/bounded-rationality (9. 10. 2020).

Zakon o ratifikaciji Konvencije o dostopu do informacij, udeležbi javnosti pri odločanju in dostopu do pravnega varstva v okoljskih zadevah. Uradni list Republike Slovenije 62/2004. Ljubljana. 